\title{
Secondary Sacredness
}

\section{Sacredness in an Information-Communication Era}

\author{
Alić S* \\ University North, Croatia
}

*Corresponding author: Sead Alić, University North, Trg dr. Žarka Dolinara 1, 48000, Koprivnica, Croatia, Tel: 00385989828592; Email: salic@unin.hr

\section{Research Article}

Volume 2 Issue 3

Received Date: July 02, 2019

Published Date: July 22, 2019

DOI: $10.23880 /$ phij- 16000120

\section{Abstract}

The era in which information rules over the prose of life, is the era that will uncover mediation as a mechanism of 'creating a surplus of symbolic value'. Man turned into a sign, a symbol, will be aware of his slavery to the idols of progress, technological glass beads, the emptiness of language and labyrinths of logical-grammatical-geometricalmathematical so-called wisdom. New forms of sacredness (which have been introduced after the holy word, holy scripture, holy places) and are revealed in the form of sacred football clubs, holy nations, etc. are merely proof of the historical process of the loss of aura which has been speeded up by mechanical reproduction.

\section{God and Sanctity in the Information Age}

Can the information age coexist with faith and religion? Is the sacredness of places, letters, books and churches today replaced by worldly forms of 'sacredness' - mass-media surrogates of faith exhausted in a mass psychology?

An important element of any religious approach is the way in which messages are transferred. Changes brought on by the world of mass-media and the speed of exchange shed particular light on the idea of sacredness and ways to live the faith. Religions and faiths face the challenge of phenomena such as information, speed and image. Mass media produce a mass psychology which in a way 'embodies' dominant technics.

In his book Media: The Second God, (dedicated to Marshall McLuhan), Tony Schwartz touches upon the problem of the divine influence of the modern mediating technique - the modern media. The beginning of the book which is better at delineating the idea of divinity in mass media than in analysing its actual content, provides the usual definition of God: "God is all-knowing and allpowerful. He is a spirit, not a body, and He exists both outside us and within us. God is always with us, because $\mathrm{He}$ is everywhere. We can never fully understand Him, because He works in mysterious ways" 1 . This is then of course followed by noting that it is precisely the media that is omnipresent, all-knowing, all-powerful, noncorporeal, present both externally as well as within us. The media is therefore imposed as a new, secondary, secular type of God, a supernatural being, although this being is clearly the product of man.

Through its technical dimension, the informationcommunication horizon obviously impacts views on culture and human community as well as the manner in which we experience the supernatural. of course, this entails people unconsciously agreeing to new types of the divine, a sort of unconscious religiousness emerging, satisfying the need for religious rituals in an unexpected

${ }^{1}$ Schwartz, Tony, Media: The Second God, Anchor Books edition, 1983, pp: 1 


\section{Philosophy International Journal}

way within an environment which wasn't planned to provide people with a sense of faith, sacredness or piety.

This follows the tradition of the many centuries that gradually brought on the change from the domination of theology to the domination of technology. Neil Postman illustrates this in his book Technopoly, The Surrender of Culture to Technology. After discussing the strength theology once had in defining what people were to do and think, among other things by using the example of how Leonardo da Vinci's submarine failed to work due to theological and not technological reasons, Postman identifies a new technological paradigm: "In a technocracy, tools play a central role in the thought-world of the culture. Everything must give way in some degree, to their development. The social and symbolic worlds become increasingly subject to the requirements of that development. Tools are not integrated into the culture; they attack the culture. They bid to become the culture. As a consequence, tradition, social mores, myth, politics, ritual, and religion have to fight for their lives"2.

Everything is so much under the influence of technology that it starts to take the leading role in the dimensions of culture, religion, politics... Technology therefore offers a new, practical logos - technique as a horizon in which all other dimensions are to be lost.

This is a warning that at the very least makes us constantly question the system of technological and media mediations. In order for us not to become serving mechanisms of our own inventions (an old warning by Marshall McLuhan) we need to constantly critically question the system of technological and media mediations. I covered this subject, as well as the need to develop awareness on media mediations in philosophical approaches in a book which raises the message as such, as well as the strength of McLuhan's syntagma "the medium is the message" to the level of requiring a philosophy which would be capable of such a thing, and this is the philosophy of media ${ }^{3}$.

For similar reasons, Regis Debray founded mediology as a scientific discipline. His idea was to examine mediation systems, that is, media in the widest sense, and the ways in which they have shaped human history. A gravestone is defined as a mnemotechnic means; the victory of the Christian idea is related to the victory of the

\footnotetext{
2 Postman, Neil, Technopoly, The Surrender of Culture to Technology, Vintage Books, New York, 1993, pp: 28

${ }^{3}$ Further reading in: Sead Alić, Philosophy of the Media is the Message, Lambert Academic publishing, 2019.
}

book code; the new carriers of information introduce new powers and weaken influences developed through old media (in this way the printing press weakened the church hierarchy and electronic media weakened party structures).

His idea of a 'portable God' is particularly interesting, i.e. the idea of a holy book replacing sacred places of worship. According to Debray, this example should clearly illustrate how the ideological is transformed into the symbolic, cultural and technological. In this sense the concept of ideology itself moves from the episteme towards praxis, i.e. towards ways of organization. The ideological is hidden within the organizational and determines the dimensions of culture and science. He uses the example of the theory of information: "Shall we be forgiven for recalling that the father of information theory, Shannon, the creator of a rigorous mathematical framework for evaluating the cost of a message, was an employee of the Bell Telephone Company? This does not of course alter the scientific value of his theorems, but suggests to us the need to limit its extrapolations (to the mechanical universe). It is not a matter of indifference that in France the administration of the Telecoms (D.G.T., C.N.E.T., etc.) should have been the principal source of financing and sponsorship of communication studies conferences, seminars, chaired professorships, journals and other publications" 4 .

This paradigm change is envisaged in Benjamin's insights on the changes introduced by the era of mechanical reproduction, Heidegger's understanding of the impact of technology and McLuhan's view of the media ${ }^{5}$.

In his probably most famous essay, The Work of Art in the Age of Mechanical Reproduction, Walter Benjamin, although starting from Valery and his idea of newness in art, and analysing art in terms of the idea that the artistic corpus should include segments which cannot be used by fascism - he finally achieves most through analysing 'nonauratic art' i.e. segments of art in the era of great technical possibilities for reproducing artworks. Benjamin suggests that the beginning of the $20^{\text {th }}$ century introduces not only the ability to reproduce a work of art but also a

\footnotetext{
${ }^{4}$ Debray, Regis, Media Manifestos, On the Technological Transmission of Cultural Forms, Verso, 1996, pp: 42.

${ }^{5}$ Gehlen, for example, writes about a 'technical model of thinking' which is a direct consequence of the influence of new techniques and the loss of sensitivity. Arnold Gehlen: Die Seele im technischen Zeitalter: Sozialpsychologische Probleme in der industriellen Gesellschaft, Klostermann Vittorio GmbH, 2008.
} 
corresponding influence of new film and photography techniques on art in general ${ }^{6}$.

Marshall McLuhan presented this influence as a system of developing human extensions which significantly impact human perception. If we are unfamiliar with these impacts, we risk becoming dependent on our own inventions ${ }^{7}$. In this sense it is important to understand terms such as sacredness ${ }^{8}$ in the context of new modern technologies ${ }^{9}$.

Of course, there is no deterministic sequence for analysing in advance the outcome of the emerging ways of mediating religious messages. Phenomena show up at times and place where we might not expect them, not in a linear, but cyclical fashion. In the same way that 'secondary orality' developed alongside the medium of radio (in a period when writing and books held the dominant position) - we now witness a sort of 'secondary sacredness' which is becoming more significant precisely in the era in which information as such has predominance. This 'secondary sacredness' is a way of unconsciously showing an almost religious respect towards our own products which are alienated and opposite to us. Since this often constitutes an unconscious relationship, it is important to understand this phenomenon.

${ }^{6}$ "Um neunzehnhundert hatte die technische Reproduction einen Standard erreiht, auf dem sie nicht die Gesamtheit der überkommenen Kunstwerke zu ihrem Objekt zu machen und darren Wirkung den tiefsten Veränderungen zu unterwerfen begann, sondern sich einen eigenen Platz unter den künstlerischen Verf arungsweisen eroberte." Walter Benjamin, Das Kunstwerk im Zeitalter seiner technischen Reproduzierbarkeit, Gesammelte Schriften, Band I-2, Suhrkamp Verlag, Frankfurt am Main, 1980, pp: 475

7 Further reading: Marshall Mcluhan: Understanding media, Routledge \& Kegan Paul, London, 1975.

${ }^{8}$ Mass Media: A Prison without Walls also mentions this analysis of sacredness, of course in line with the ideas by Guy Debord and Regis Debray: "The sacredness of holy places which has become a portable sacredness with the emergence of writing, enabled man to have a 'bookish' type of participating in sacredness. Sacredness which can be transported through writing becomes the sacredness of writing. The specific medium of the book has become the patron of monotheistic religions. Mediology was thus announced in the form of theology. It is as if form has been separated from its original content and started setting its own conditions. Photography entails a similar process." Sead Alić: Mass Media: A Prison without Walls, Centre for the Philosophy of Media, Zagreb, 2012.

9 In the late 19th century, the camera becomes a magical 'failsafe' box, especially in advertisements. Having faith in such a photographic type of truth becomes the dominant form of faith in truth in the 20th century.
Thought has the role of delving into the essence of changes in the way the religious phenomenon of sacredness is experienced, practiced and in its impacts, through analysing technological aspects of media mediation. Thinking should be defined in relation to these changes. Through mirroring each other, thinking and sacredness have the task of resounding in concepts adequate to the modern consciousness.

Self-aware thinking has to start from a self-aware position of a philosopher as researcher of the connections between the spiritual and the signs/symbols of mediating this inwardness towards the world.

\section{Self-Questioning of One's Own Existence}

When we try to say or read the sounds we have shaped in visual symbols, we actually return them into speech. We speak ourselves as beings in the shape of words for which it is supposed that they can express something important or essential about our being.

My being, for example, may be an example of questioning how much I can even express in letters, sounds, grammatically shaped (to a certain extent logically based) sentences on the omnipresent being. And vice-a-versa, it would be easier to be, if awareness of the omnipresent was clearer, to others and to myself.

Like a dancer in magic and ritual, through talking we play with rhythm and melody. This time with the rhythm and melody of a sentence. We stress some words, lower and raise the tone, keep the tension of thoughts concentrated on pushing through to representing the organization of the text as the organization of words reaching the cooperation of that which is spoken with that which is described.

I entwine the mystical oneness of our being with the overall being, this time through words which have developed from inarticulate screams, sounds of wonder and fear, from ways to express the wish for food or sex into attorneys representing human souls.

And I fear that, just as lawyers do not care much about the truth, my words/our words do not care about truth either. Or perhaps to put it more correctly, they do not care about revealing their own being in the omnipresent as a form of simultaneousness and union, the knowledge of the omnipresent being. Of course, not because this is something I do not want. It seems to me, and the history of thought provides many supporting arguments, that insisting on the logical-grammatical, almost geometrical- 
mathematical preciseness of terms alongside their simultaneous inability to reach being - represents a trap and a labyrinth.

I use words. I use them for not understanding the traces of animals on this earth, for losing my way in rainforests and savannahs, in order to avoid the inarticulate wonder when confronted with the unutterable. And I calmly (admit that I) do not understand the environment I live in and even more calmly (I admit that I) enter the lines of printed words (today's zeroes and ones) because here I feel at home. I feel anxious but the walls of letters are familiar. And although I feel like I am under house arrest, I get by. The thought that I exist (as a potential) closer to myself, and the world to which I could be closer also exists, gives me strength to examine the familiar spaces of words ${ }^{10}$.

Few people have not felt moments of doubt, weakness, emptiness and anxious despair when they question the purpose of delving into worlds of words, signs, symbols and their meaning. At the time of noting this scepticism of mine, I could have euphorically and in a Dionysian fashion spent time with my friends, explored the erotic shapes of corporeal joining with the other (depending of course on the amount of energy the body still held in store). I could have been an activist raising and lowering protest banners, supported a political party, developed a so-called business (earning money on other people's troubles). Instead of this, I use philosophy and spaces beyond to question myself as one of the billions streams of human existence throughout history. I compare and seek particularities and similarities, the loss and gain in comparison to what man could or should be.

The assumption is probably that, as I put under control my inarticulate sounds and as I learn to lose my way without words under the starry sky, in articulate sounds visualized in words I shall find my individual being better in union with the universe - the universal being, the being under which my own personal being also exists ${ }^{11}$.

${ }^{10}$ Cassirer's Philosophy of Symbolic Forms has opened new horizons of reflection on the symbol culture. In his analyzes of myth, language, and number - is the way of self-expression of selfconsciousness Ernst Cassirer: The Philosophy of simbolic forms II: Mythical Thought, New Haven: Yale university press,

London' Geoffrey Cumbel"lege . Oxford University Press 1955. (Myth as a Form of Intuition. Structure and Articulation of the World of Time and Space in the Mythical Consciousness, 71-140).

${ }^{11}$ This text was inspired by Cassirer, but also by Walter Benjamin and his understanding of language: "What does language communicate? It communicates the mental being corresponding to
By saying words out loud, in a way I certainly exist. Here and now and with no scepticism, by saying more or less articulate words, I prove: that I have decided to try and give myself true existence in a roundabout way through words that have their own meanings; that I have been educated, trained, disciplined, civilized, shaped... so that I don't question words as arguments in the legal process with the universal being. I also prove that I am part of some culture which sweeps most of its problems under the carpet, i.e. a civilization that in the name of its progress works on its self-destruction. I prove finally, and in an indirect way, that my being through words, sentences, grammar, logic, metaphors, metonymies, signs, symbols, buildings that rise up on the basis of all of these - is closest to that universal being.

At the same time, I fear that each of my victories has served to distance me from the problem. The more I write, the less I try to remember, with the availability of transport options I walk less and less, confronted with all the happy endings in movies, I am less happy, with different human sentences of grammatical and logical interpretations of God, I am moving farther away from what this word should signify.

The fact that we can calculate, right down to a millimetre, where and when in the Earth's orbit, or even further, two aircrafts sent by us humans from Earth will meet, proves the success that partly also signifies our failure. I live in a neighbourhood with people like me, who

it. It is fundamental that this mental being communicates itself in language and not through language. Languages, therefore, have no speaker, if this means someone who communicates through these languages...

What is communicable in a mental entity is its linguistic entity. Language therefore communicates the particular linguistic being of things, but their mental being only insofar as this is directly included in their linguistic being, insofar as it is capable of being communicated." Walter Benjamim: Selected Writings

Volume 1 1913-1926 Edited by Marcus Bullock and Michael W. Jennings, The Belknap Press of

Harward University press, Cambridge, Massachusetts London , England p. 4.

"Was teilt die Spracje mit? Sie teilt das ihr entsprechende geistige Wesen mit. Es ist fundamental zu wissen, dass dieses geistige Wesen sich in der Sprache mitteilt und nicht durch die Sprache. Es gibt also keinen Sprecher der Sprachen, wenn man damit den meinst, der durch diese Sprachen sich mitteilt. Das geistige Wesen teilt sch in einer Sprache und nicht durh eine Sprache mit - dass heist: es ist nicht von aussen gleich dem sprachlichen Wesen... Die Sprache teilt also jeweilige sprachliche Wesen der Dinge mit, ihr geistiges aber nur, sofern es unmitelbar im sprachlichen beschlossen liegt, sofern es mitteilbar ist." Benjamin, Walter, Über Sprache überhaupt und über die Sprache des Menschen, Gesammelte Schriften, Band II-1, Suhrkamp Verlag, Frankfurt am Main, 1977, pp: 142. 
put the success of mathematics above everything, including my attempt at understanding my own inarticulate scream which I long to reach every time I see a wild animal of hypocritical word in the rainforest of illiterate academics and ideologues.

Each word in which my being is not present - is my defeat. This is how a man for whom it is important to understand himself should think and speak. The morning flash in which the omnipresent opens itself to my consciousness, suggests that there might be a way out, a way to unveil eyes which have been used to interpreting symbols in the dark... A thought that comes to me before sleeping (which I am too lazy to write down in order not to wake) is proof that this is not mine, it offered itself to me, came to my doorway like happiness, but fear, tiredness or laziness told it no-one was home.

I am who I am, but in what way am I? Am I trying to exist in the way of the one who symbolically revealed himself to us with the words I am who I am? I am part of the ordered world appearing and disappearing, speaking in its forms, natural phenomena, changes, movements or stillness. I wander and I wonder: Can thought return me to unity?

In the beginning was the Word. Fine. But in the beginning of this tale of mine there also was the Word. Through it I am trying to reach and explain to myself the essence of my being. In the beginning of each civilization that separated itself from shouts and screams, dancing and inarticulate voices - is the word. Isn't the result proclaimed to be the cause? What if victory becomes defeat because throughout history words keep returning us to its impossibility to create unity between man and universe.

Thinking on God, we follow the steps leading to rational religion. Rudolf Otto thought this was not enough $^{12}$. But is his move towards the irrational as a

\footnotetext{
${ }^{12}$ This bias to rationalization still prevails, not only in theology but in the science of comparative religion in general, and from top to bottom of it. The modern students of mythology, and those who pursue research into the religion of primitive man and attempt to reconstruct the bases or sources of religion, are all victims to it. ." Rudolf Otto: The idea of the Holy. An Inquiry into the Non-rational Factor in the Idea of the Divine and its relation to the rational, Oxford University Press London : Humphrrey Milford, 1936. p. 3/4 („Dieser Zug zum Rationalisieren herrscht bis heute noch vor, und nicht nur in der Theologie sondern auch in der allgemeinen Religionsforschung bis zum untersten hin. Auch unsere Mythen-forschung, die Erforschung der Religion der 'Primitiven', die Versuche zur Konstruktion der Ausgänge und Anfangsgründe der Religion usw. unterliegen ihm." Rudolf Otto: Das Heilige. Über das Irrationale in der
}

dimension containing that part of the sacred and divine, which cannot be reached through predicates of thought the same as the subject of his critique, just an attempt to reach rationally (i.e. rationalize) something that is not rational ${ }^{13}$.

For example, when talking about music, ${ }^{14}$ he uses rational means, a metaphor, to suggest the impossibility of conceptually reaching the essence of musical beauty. But that is an analogous discussion which raises a parallel but does not go into the irrational to explain it in some new medium.

When discussing the primal fear which is surely one of the key feelings held by the small human speck of dust before the universal, he concentrates on a non-realized feeling of the man of the myth. If this is the basis for constructing the concept of the numinous which should reach that non-rational, non-thinking segment of the sacred or divine - then he is actually taking out from the mythical past one human feeling in order to prove through it something that does not even have to be proven. The sense of irrational fear is the feeling felt by the man of myth when confronted with a non-thinking community which is not organized through thinking or the thinking industry, in which man with his symbols, thoughts, concepts, metaphors, metonymies - enters into a somewhat safe world which in its familiarity reminds him of the womb in which he matured to take his first breath and cry.

Idee des Göttlichen und sein Verhältnis zum Rationalen, Verlag C.H. Beck München 1963. p. 3).

${ }^{13 " I}$ adopt a word coined from the Latin numen. Omen has given us ominous, and there is no reason why from numen we should not similarly form a word numinous". Rudolf Otto: The idea of the Holy.

An Inquiry into the Non-rational Factor in the Idea of the Divine and its relation to the rational, Oxford University Press London : Humphrrey Milford, 1936. p. 7.

${ }^{14 " M u s i c, ~ i n ~ s h o r t, ~ a r o u s e s ~ i n ~ u s ~ a n ~ e x p e r i e n c e ~ a n d ~ v i b r a t i o n s ~ o f ~}$
mood that are quite specific in kind and must simply be called
musical ; but the rise and fall and manifold variations of this
experience exhibit though again only in part definite, if fugitive,
analogies and correspondences with our ordinary non-musical
emotional
states, and so can call these into consciousness and blend with them.
If this happens, the specific music-consciousness is thereby
schematized and rationalized, and the resultant complex mood is, as
it were, a fabric, in which the general human feelings and emotional
states constitute the warp, and the non-rational music-feelings the
woof. The song in its entirety is therefore music rationalized“.Rudolf
Otto: The idea of the Holy.

An Inquiry into the Non-rational Factor in the Idea of the Divine and its relation to the rational, Oxford University Press London : Humphrrey Milford, 1936. p. 49. 
My sentence is crucified between beginning and end, its birth and final position. In synergy with others it tries to understand my existence, and in this, existence as such: the indelible memory of the moment when as a child I became aware of my own separateness and a reliable strong sense of increasing weakness.

We are all at the cross of our sentences, but not only because others can judge us for them. We are condemned to the cross of our sentences. The sentence is our way of the cross. The stations on this way of the cross are forms of logically and grammatically shaped attempts at redemption. Man had to come up with the idea of a God on the cross because he needed a symbol for all the miseries into which history has plunged us through words as consequence, sentence as a means and sidetrack to knowing the Universe.

In order to be certain of our answers, we need to reexamine our questions: are we asking the right questions, or to perhaps put it more correctly, are we expecting solutions and answers, a way out in the right horizon. Are we questioning in the right place and the right way?

The question of God and the created world has always provided a starting point for generating all other questions and horizons of answers. The history of philosophy is a history of worldly theology. Throughout history theology has at the same time been a system of rationalizing something for which it is questionable that it can be reached by reason, thinking, logic or science.

Therefore, in my opinion the root of the question on God and the created world, is actually the question on the medium of the correlation between man and God ${ }^{15}$.

\footnotetext{
${ }^{15}$ Walter Benjamin's words: „Or, more precisely, that all language commUnicates Itself in itself; it is in the purest sense the "medium" of the communication. Mediation which is the immediacy of all mental communication, is the fundamen:al problem of linguistic theory, and if one chooses to call this immediacy magic, then the primary problem of language is its magic". Walter Benjamim: Selected Writings Volume 1 1913-1926 Edited by Marcus Bullock and Michael W. Jennings, The Belknap Press of Harward University press, Cambridge, Massachusetts London, England p. 64

„,...jede Sprache teilt sich in sich selbst mit, sie ist im reinsten Sinne das 'Medium' der Mitteilung, ist das Grundproblem der Sprachtheorie, und wen man diese Unmittelbarkeit magnisch nennen will, so ist das Urproblem der Sprache ihre Magie“. Benjamin, Walter, Über Sprache überhaupt und über die Sprache des Menschen, Gesammelte Schriften, Band II-1, Suhrkamp Verlag, Frankfurt am Main, 1977., p. 142/3
}

I believe it is too great a burden for man that the absolute is self-realized through him i.e. through his art, religion and philosophy. I believe it is actually too pretentious stating that the absolute may be self-realized (through a logical and grammatical structure to which man living on the speck of dust in the universe is condemned).

Does the galaxy in the summer sky offer itself to our eyes so that we would think on it, experience it, for it to awaken feelings of grandeur and fear before the unknown and limitless, our own futility?

The sanctity of the moment before the sanctity of the infinite and unutterable.

\section{Sacredness as a Confession of Helplessness and Lack of Understanding}

After several thousands of years of literacy and misconceptions that words set in letters carry the sacredness of human being, we now face the breakdown of archival spirit. My being is outside the sentences I visit and sentences through which I aim to connect my own being to the universal. Occasional flashes inform me that through some spontaneous word I have opened myself to a dimension I do not understand, cannot describe or keep within.

Times of cleansing are upon us, as fences of words have now reached the walls of reason. Plurality sheds new light on something that once represented the hope of the emerging written culture. But today we are becoming more aware that we, the scribes, have become merely the followers of the cult of the word. We fail to see that in the different meanings of words, their metaphors and symbolism - there lives that same fuzziness we opposed when we opposed the golden calf, totems and other human attempts at bringing man, the so-called primitive man, closer to the universal being.

Times are approaching when we shall bow down to that kind of sacredness which has not even entered the word, which does not have its rituals and has lived through the swords of pens and cannons of the printing press as well as the electronic landfills of spirit and digital hypnotic toys.

I would like to suggest a direction for opening towards understanding sacredness in one mental image, and alongside this, towards lesser known pathways of thinking on the birth of theological and philosophical thought, that is, roads which might serve as a way of 


\section{Philosophy International Journal}

apology towards cultures from which we stole and simultaneously looked down upon.

I shall use the apparently banal image of a sick person awaiting his/her departure (any similarities with the civilization we live in is accidentally on purpose).

Each of us today is either healthy or sick, just as any other person living 5000 years ago. But we forget. We fail to do research. Through some strange collective mistakes, we sweep facts under the carpet: in today's treatment of our diseases, without being aware of the fact, we use the knowledge on plants and medicine held by people who lived three or four and five thousand years ago. It is possible that some types of knowledge and methods from the oral tradition are even older ${ }^{16}$.

At the same time, we tend to find ways to reject whole periods and cultures by using their explanations on the usefulness of individual plants. We'll need one or two thousands of years to discover that some method or plant has been used correctly for a certain disease because modern research has shown these possess ingredients contained in modern drugs. But the part relating to the explanations on why they used these do not mean anything to us or have even posed an obstacle to serious research on the efficiency of their treatment.

Our construction of God, our philosophical systems, scientific paradigms, all of this has a priori created within us psychological reflexes of disgust towards anything that does not represent some sort of unity between the religious-philosophical-scientific-mass-media-ritualistic.

Egypt, Mesopotamia, India, China, South America these were the lands of civilizations that celebrated life, which in many segments were more advanced than Ancient Greece, but Greece was lucky in that it completed the process of turning pictorial into phonetic writing, creating a medium through which it opened up to the coming centuries and became the spokesperson for the mute, oral, cuneiform, hieroglyphic... times.

Athenian and Greek culture which perfected the medium of all media - language - served as a prototype for shaping scientific, political, artistic and even religious existence ${ }^{17}$. On the limits of the dense fog made out of

\footnotetext{
${ }^{16} \mathrm{An}$ interesting book about it was written by Jürgen Thorwald: Macht und Geheimnis der frühen Arzte, Verlagsanstalt Th. Knaur, München, 1985

${ }^{17}$ Further reading in: Medium of the Language in the book Sead Alić: Philosophy of the Media is the Message. Lambert Academic publising, 2019..
}

literacy that is difficult to understand and an even greater fog of complete orality, there grew a wall with guards (consonants and vowels) a wall that has stood throughout the times, which like the river Lethe from Greek mythology exists so that psyches returning my turn into aletheia (unconcealment) i.e. that which is higher and deeper than truth itself.

But the medium is everything. We receive messages from former times in the methods for operating the human skull, making a Caesarean section, measuring the pulse, researching the impact of certain plants on diseases and many other things, all of these used thousands of years before we as humans rose to the level of phonetic writing, the medium in which we can transfer information through time in an economical and successful fashion.

In this sense, the fear we talk about when we discuss the concept of sacredness, becomes a specific fear of a person who was living thousands of years before us and experienced a moment between life and death. Illness as a lack of health had to come as a sort of punishment (or that is how it could have been interpreted by the priesthood). Someone who failed the conditions set by the priesthood and got ill, became an example and was punished by forces of whom priests were representatives.

The fear of God or towards God probably appeared together with fearing for one's own human life, that is, one's health. Sickness of an organ or the whole body was a sign that as humans we are helpless, limited, mortal - we need the help of the doctor-priest.

Whoever dipped into the history of philosophies in various parts of the world, saw of course the patterns in relating philosophical and medical knowledge. At the same time there exists a parallel in relating priestly and medical knowledge. The common denominator can be called by different names but it certainly contains questions on the purpose of human life, death, life as such, time, life after death, order, God, birth and death of humans, creation and destruction of the world, sacredness...

Sacredness is therefore, just as any other concept, a product of our own limited existence. It is our need and a tool we use at moments when we start drifting towards our own ending. Sacredness is one of the answers to our inability to understand the world we live in and how it was created, i.e. our transience ${ }^{18}$.

${ }^{18}$ New Holiness Brings New Angels : „The media are everywhere and nowhere. They are a spirit, a disembodied entity occupying no space 


\section{Philosophy International Journal}

Casting our eyes towards medicine is an attempt at measuring the height of the pyramid by using its shadow. The knowledge of the philosopher-doctor cannot be such that the medical aspect was so advanced and only today we discover it as relevant and that the philosophical one was so backward that it should be uninteresting. We have made some mistake in understanding ancient times or we make this mistake constantly.

Every disease used to mean yielding the body to demons due to some sin. In order to free ourselves from demons, we covered our bodies in excrement, urine and plants, drank their fluids and found out much later there was actual basis in this. We discovered that some important ingredients of modern drugs are contained within these plants or even in urine. This is the space in which the fear of dying created priest doctors who in an almost magical fashion (through trial and error) offered solutions which for a long time remained unclear to us. They were unclear of course due to our lack of knowledge, and this came from ignoring the link between philosophy and everyday life, the link between philosophical, theological and medical concepts or instructions.

Long before the Greeks thought that air (pneuma) could be the origin of everything, Indian philosophy measured the number of our daily breaths and suggested ways of breathing to provide us with peace, calm and unity between our individual and the universal spirit. If philosophy is silent on this account - medicine is not.

But to my existence, to my being, today it is crucial whether I know how to breathe, whether I can harmonize my breath with the universal spirit. The bureaucratic separation between scientific branches and fields is no longer important. I feel cheated. My being which holds within the beings of billions of people that existed before me, feels falsely separated and made unhappy. Robbed for the possibility of a more universal existence.

If doubts exist, and they most certainly do, on the relation between the Jewish and Egyptian people and if interpretations have entered into areas of myth and holy books - still Freud's medical question remains: why are Jews circumcised if it is known that this was the tradition of old Egyptians? What historical and mythological walls have been erected between the two nations sharing the same medical approach to one phenomenon (which in

and all space at the same time. The electronic voices we hear have no body. In fact, the entire output of electronic media is invisible. The late Marshall McLuhan called it 'angel-like'". Schwartz, Tony, Media: the second God, Anchor Books edition, 1983., p. 4 any case appeared in geographically close areas?) There are therefore medical facts which can question mythological wordplay, that is, codes set to music following the needs of future generations ${ }^{19}$.

In the same way that there is a close connection between breath and spirit, there is great familiarity between areas of human health and the ideas of the sacred, universal, religious as well as philosophical.

And while religious and philosophical concepts play hide and seek dancing through history, changing their masks and roles, medicine as a horizon of birthing the sacred provides insights which go behind the curtain of the two rulers, theology and philosophy.

Thousands of years before the immovable mover or the thinking of thought, before the idea that air could be the origin of life, or that there is order in the universe which might be shown through geometry, arithmetic, logic or even grammar - worlds existed that from individual human destinies, based on thousands and thousands of trials and errors, made conclusions based on which, stone by stone, buildings of theological and philosophical worldviews would be constructed.

One of the key moments for philosophy and theology is the question: Where and why could the idea of sacred appear and in what actual shape? ${ }^{20}$

If we leave aside subsequent interpretations or theological and philosophical adaptations of the drama of birth of the sacred, it appears that it is precisely medicine that offers a crack/narrow passage towards unasked questions or areas that have not been properly researched yet.

Europe, whose opinion dominates the world, is smug with the stereotype it has on the beginning of the European civilization, or world civilization as such - that

\footnotetext{
${ }^{19}$ This question is not related to the question of why Freud (in his last work) analyzes Moses. Richard J. Bernstein in the book Freud and the Legacy of Moses analyzes the theses of a series of authors such as Jacques Derrida, Yosef Yerushalmi, Jan Assmann, Paul Ricoeur. All of them were trying to answer the question Why Freud claims that Moses was an Egyptian. Richard J. Bernstein argues that Freud does not argue his attitudes, and that his analysis is a kind of historical novel. Richard J. Bernstein: Freud and the Legacy of Moses, Cambridge University Press, 1998. Pp: 20.

${ }^{20} \mathrm{An}$ interesting suggestion is given to us by Tery Eagleton: „The word 'sacrifice' literally means 'to make sacred'. Sacrificial rituals involye taking some humble or worthless piece of life and converting it into something speciai and potent". Terry Eagleton: Holy Terror. The meaning of Terrorism. Oxford University Press, 2005. p. 129 .
} 


\section{Philosophy International Journal}

is, ancient Greece. In the area of conceptual thinking, there is almost no possibility to oppose Eurocentrism. But thinking that truly aims to understand the source of every phenomenon relating to the human being, must step backward and examine civilizations which for at least two or three thousands of years, developed ideas for transforming human knowledge into a concept to be transferred to future centuries.

That which is directed forwards does not have to be good as a means of examining what has been left behind. The medium of concept in the philosophical sense, just as the progress of religious thinking from mythical to monotheistic religions, certainly does not have to be the best means for examining the past. Mainly because both approaches require reflection on the events, manner, approach. And we are returning to an era of direct experiments and birthing of basic suspicions based on which later ideas of phenomena shall grow into concepts.

At the end of announcing these needed changes, let us try and answer questions we have posed in a summary of this text.

The era in which information rules over the prose of life, is the era that will uncover mediation as a mechanism of 'creating a surplus of symbolic value '. Man turned into a sign, a symbol, will be aware of his slavery to the idols of progress, technological glass beads, and the emptiness of language and labyrinths of logical-grammaticalgeometrical-mathematical so-called wisdom.

New forms of sacredness (which have been introduced after the holy word, holy scripture, holy places) and are revealed in the form of sacred football clubs, holy nations, etc. are merely proof of the historical process of the loss of aura which has been speeded up by mechanical reproduction.

The so-called mass-media create masses. Mass has its laws. In this way mass-media surrogates of faith are an insult to faith and religion but at the same time they question the forms of sacredness in which sacredness has until now been imprisoned ${ }^{21}$.

We are. I am being. Sentence becomes ungrammatical if it wishes to approach that which I intuitively know.

${ }^{21}$ Terry Eagleton wrote that terror began as a religious idea. Terry Eagleton, Holy Terror. The meaning of Terrorism. Oxford University Press, 2005.
My being is to go on the path of return. Through the wasteland of history created due to the impact of holy words, technical tools, the false idea of progress.

My being says that human existence shall face high expanses of true sanctity reached for brief moments by the consciousness of people in all cultures, faiths, the socalled civilizations ${ }^{22}$.

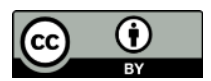

${ }^{22}$ But not necessarily in the way of Rudolf Otto, ending in divinity (testimonium Spiritus sancti internum). Otto writes: „Let us call the faculty, of whatever sort it may be, of genuinely cognizing and recognizing the holy in its appear ances, the faculty of divination". Rudolf Otto: The idea of the Holy. An Inquiry into the Non-rational Factor in the Idea of the Divine and its relation to the rational, Oxford University Press London : Humphrrey Milford, 1936. pp: 148 („Das etwaige Vermögen, das Heilige in der Erscheinung echt zu erkennen und anzuerkennen, wollen wir Divination nennen." Rudolf Otto: Das Heilige. Über das Irrationale in der Idee des Göttlichen und sein Verhältnis zum Rationalen, Verlag C.H. Beck München 1963. p. 173.) 